\title{
Acesso aberto à literatura científica: as pesquisas realizadas em universidades públicas devem ter seus resultados livremente disponibilizados na Internet
}

Open access to scientific literature: research carried out in public university must have their results freely available on the Internet

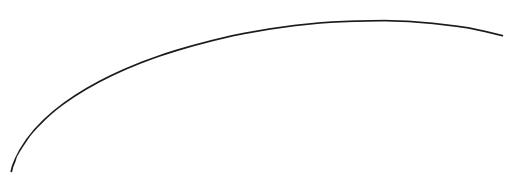

Correu recentemente pela Internet um manifesto assinado por diversos cientistas eminentes do mundo todo, colocando-se indisponíveis para emitir pareceres e / ou publicar resultados de suas pesquisas em periódicos científicos de algumas instituições privadas. A maioria dessas empresas cobra dos pesquisadores a submissão de artigos científicos e o acesso na Internet depois de publicados - esta última etapa é extensiva a qualquer leitor. Agrege-se que a revisão por pares é realizada sem custos para as editoras.

Observemos que essas empresas - editoras científicas comerciais - não realizam pesquisas e tampouco as financiam. No caso brasileiro, a quase totalidade das pesquisas é financiada com recursos públicos e os pesquisadores que as implementam trabalham, majoritariamente, em universidades públicas. Esses mesmos recursos públicos dão suporte às publicações em periódicos e a seu acesso. O desequilíbrio nessa relação entre instituições públicas fontes de recursos para realização de pesquisas e empresas comerciais que disponibilizam artigos na Internet é por demais evidente.

As iniciativas que se consolidam com base do livre acesso aos artigos científicos na Internet devem ser especialmente valorizadas, seja pelo potencial de modificar substancialmente essa relação público-privado, seja por seu caráter democrático em relação à disseminação dos produtos originários da lida nos espaços da ciência.

A nossa Revista Brasileira de Geriatria e Gerontologia inscreve-se, declaradamente, nesse movimento internacional pelo livre acesso a artigos científicos na Internet. Busca, contando com forte dedicação de sua equipe, elevar, a cada número, seu padrão de qualidade com vistas a alcançar inserção nas bases de indexação orientadas por ideais identificados com o livre acesso on line.

Participe desta iniciativa encaminhando-nos seus artigos - sem custos para os autores e sempre disponíveis à sociedade gratuitamente em textos completos, após qualificada revisão por pares. 